\title{
THE USE OF STATISTICAL ANALYSIS IN THE LITHOSTRATIGRAPHY \\ OF SUBMARINE FAN DEPOSITS. AN EXAMPLE FROM SOUTHEAST GREECE (KARPATHOS ISLAND)*
}

\author{
G. Pantopoulos', P. Konstantopoulos', A. Maravelis', \& A. Zelilidis' \\ ${ }^{1}$ Department of Geology, Laboratory of Sedimentology, University of Patras, \\ 26500 , Patras, \\ gpantop@upatras.gr,Tkonstan@upatras.gr,amaravel@upatras.gr, \\ A.Zelilidis@upatras.gr
}

\begin{abstract}
Examples of various types of statistical analysis of submarine fan bed thickness distributions that have been proposed in the past are reported, as well as an example of their application in Late Eocene-Oligocene submarine fan deposits of SE Greece (Karpathos Island). Generally, the sandstone bed thickness data measured in two outcrops of Karpathos submarine fans seems to follow power law (fractal) cumulative distributions. A deviation from the power law was observed as amalgamationprocedures become more frequent. These observations gave important information about Tertiary turbidite sedimentation in the area which probably was punctuated and had a single main sediment source. Information taken from statistical analysis of submarine fans bed thickness data has immediate applicability in hydrocarbon exploration because sandstones constitute ideal reservoirs.
\end{abstract}

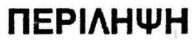

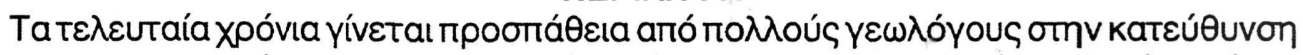

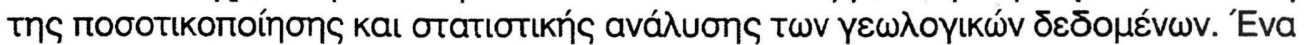

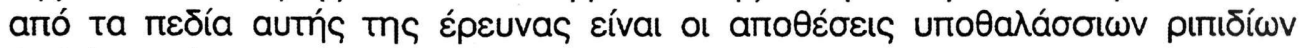

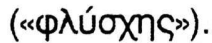

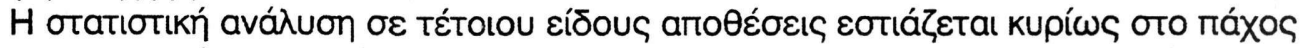

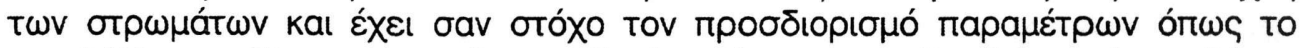

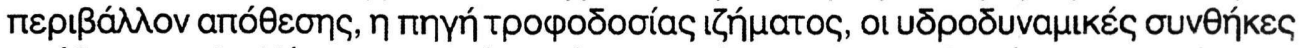

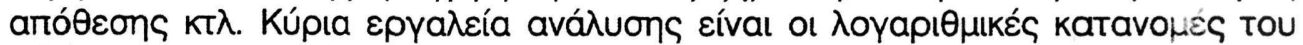

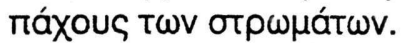

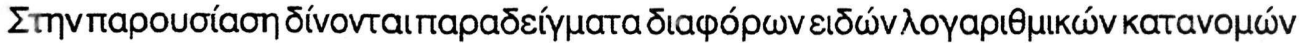

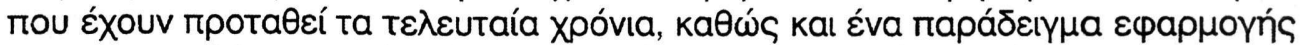

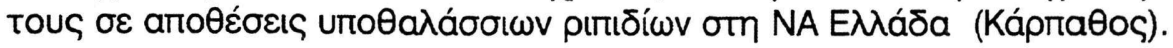

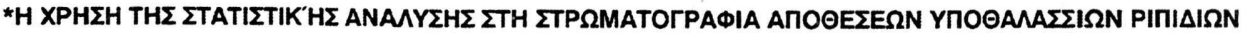

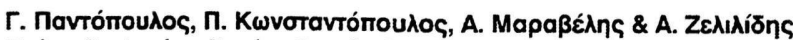

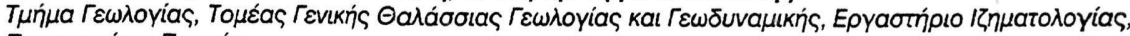

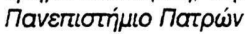




\section{Introduction and geological setting}

Submarine fan deposits are the product of deposition of turbidity currents which are caused by submarine failures and landslides on the continental slope. They generally consist of sandstonemudstone alternations with characteristic sedimentary structures like graded bedding and the Bouma sequence (Bouma 1962). The current study attempts to find information about turbidite deposition based on the statistical analysis of turbidite sandstone bed thickness patterns. The study area (Fig. 1) is located in the island of Karpathos (SE Greece). Karpathos constitutes a part of the External Hellenides. Submarine fan deposits of Late Eocene-Oligocene age (Christodoulou, 1960, 1967; Davidson 1974, Fitrolakis 1989) are observed in 2 regions of the island, a northern region (Spoa-Olympos-Diafani) and a southern region (Pigadia-Aperi). The exposed thickness of the submarine fan deposits is less than 1000 meters, in contrast with that in Western Greece (over 3000 meters).

The submarine fan deposits probably constitute a foreland basin fill. The aim of the present work is to contribute in the comprehension of deposition and stratigraphy of the submarine fan deposits with the help of statistical methods. Better understanding of turbidite deposition in the area will give precious elements for the paleogeographic arrangement and development of the External Hellenides and more specifically of the foreland basin fills in SE Greece.

\section{Methodology- Submarine fan envi- ronments and bed thickness data}

The main model for the recognition of turbidite depositional environments was established in the early 70 's by Italian geologists who studied outcrops of ancient turbidite sequences in the Spanish Pyrenees and the Italian Apennine mountains (Mutti \& Ricci Lucchi 1972). This model suggests that turbidite deposition takes place in a submarine fan which is formed between the continental slope and the abyssal plain. Within this fan, turbidites accumulate in several depositional environments others proximal and others distal to the sediment source producing different sedimentary characteristics, bed geometries, sand-shale ratio and upward thickening or thinning bed trends which are used to discriminate different depositional environments.

This model, with some modifications over the years, is used by geologists until today but its descriptive nature frequently causes problems in identifying depositional environments in outcrops that does not display the sedimentary characteristics which the model suggests. Due to the fact that identification of submarine fan depositional environments is important in hydrocarbon exploration of clastic deposits, a necessity for a more quantitative and robust identification tool was highlighted.

This quantitative approach evolved due to several researchers during the last years, and focused mainly in the statistical analysis of turbidite bed thickness patterns in order to extract information about submarine fan depositional environments. This study focuses on four different statistical approaches those of Malinverno (1997), Carlson \& Grotzinger (2001), Talling (2001) and Chakraborty et al. (2002) and our application to the above models on bed thickness data from Karpathos Island turbidites (SE Greece). 


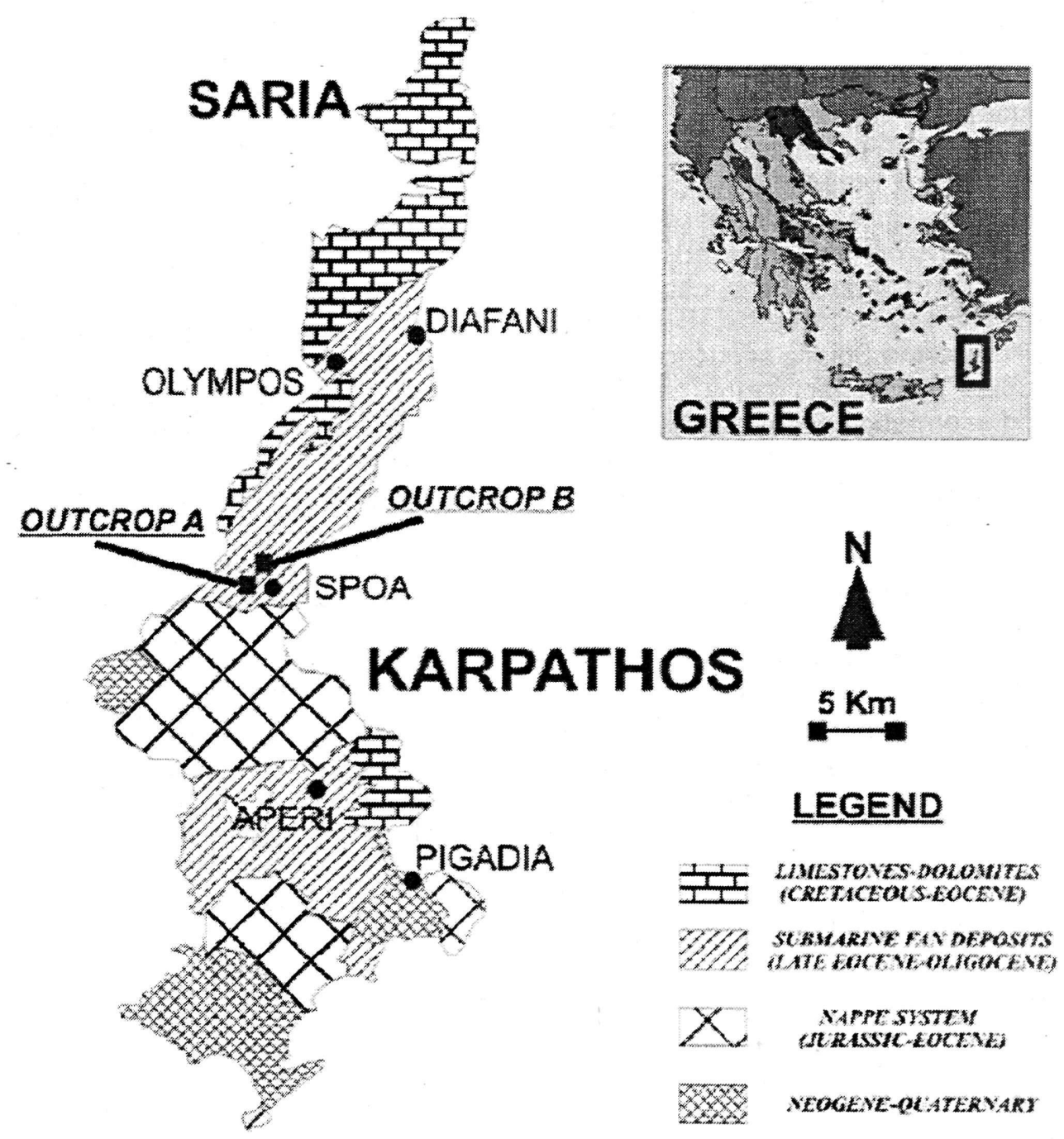

Fig. 1. Geological map of Karpathos Island. The positions of the two studied submarine fan outcrops are observed.

\section{Quantitative models}

\subsection{Carlson \& Grotzinger}

This approach focuses in the discrimination of submarine fan depositional environments based on cumulative bed thickness distributions in log-log plots. Straight lines in this type of plots indicate power law (fractal) distribution of bed thickness which expresses scale invariance and self-similarity of the tur- bidite system.

According to Carlson \& Grotzinger (2001), a power law cumulative distribution of turbidite bed thickness, expresses an environment of deposition with minimal erosion and amalgamation probably distal to the sediment source while as long as the distribution becomes more curved expresses an environment more proximal to the sediment source 


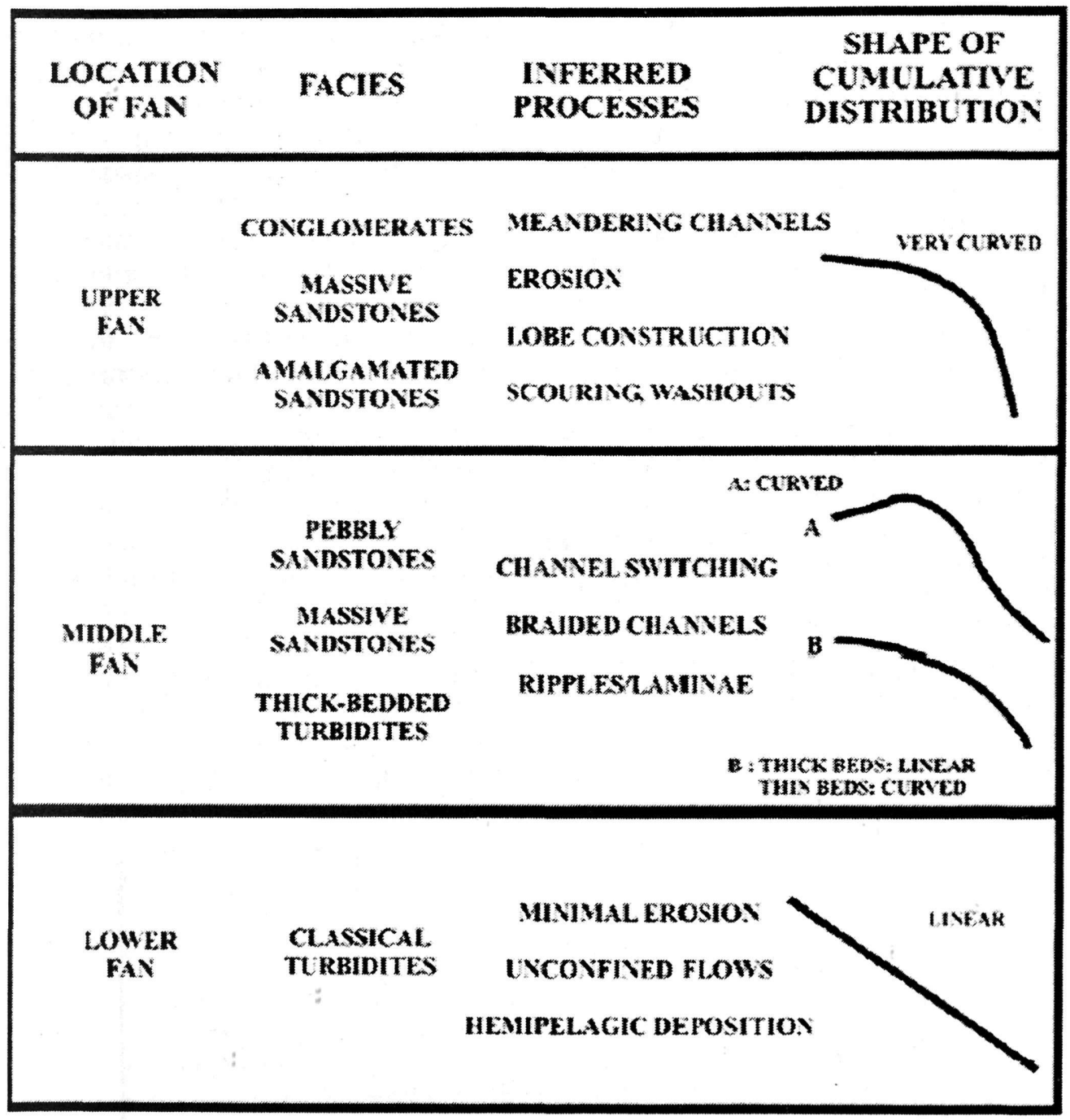

Table 1. Relation between the shape of cumulative distribution of beds and submarine fan environment, faciesand inferred processes (Carlson \& Grotzinger 2001).

in which erosion and amalgamation are frequent (Table 1).

\subsection{Talling}

Talling (2001) has looked at bed thickness data from the Marnoso-Arenacea Formation in Italy and a number of other formations and suggested that an alternative to the power-law model was a lognormal mixture, that is, turbidites starting with the same Bouma division tend to have a lognormal distribution. When two or more of these populations are mixed, the result will be a curved line on the cumulative log-log plot that might be (mis)interpreted as a segmented power law. Most turbidite successions then could be described 
in terms of two lognormal distributions largely corresponding to beds deposited by low density and high density turbidity currents.

\subsection{Chakraborty et al.}

Chakraborty et al. (2002) studied bed thickness distributions from submarine fan sequences in the Andaman Islands (India), and supports the view that the resulting distributions are the product of complex factors such as sediment source and tectonic arrangement of the sedimentary basin.

Power law distributions were observed in slope turbidites with sediment supply solely from the outer arc. On the other hand, outer fan successions with mixing of sediments from different sources show a negative exponential distribution of bed thickness.

\subsection{Malinverno}

Malinverno (1997) focuses his study on the relation between bed thickness distributions and the geometrical characteristics of the turbidite beds. If turbidite sandstone thickness is expressed by power laws and it is assumed that sandstone bed shape is well described by disc-like bodies with circular bases inside a mudstone matrix, then a relationship between the power law exponent of bed thickness and the exponents of the geometrical characteristics of the beds (bed volume, spatial distribution, thickness-bed length relation) can be found (Table 2).

If there is independent geological evidence that the turbidites have deposited in a confined basin, the relationship can be simplified and the exponents of bed volumes and thickness-bed length relation can be calculated by the exponents of the segmented cumulative bed thickness distribution.

Malinverno's approach gives important information about the three dimensional

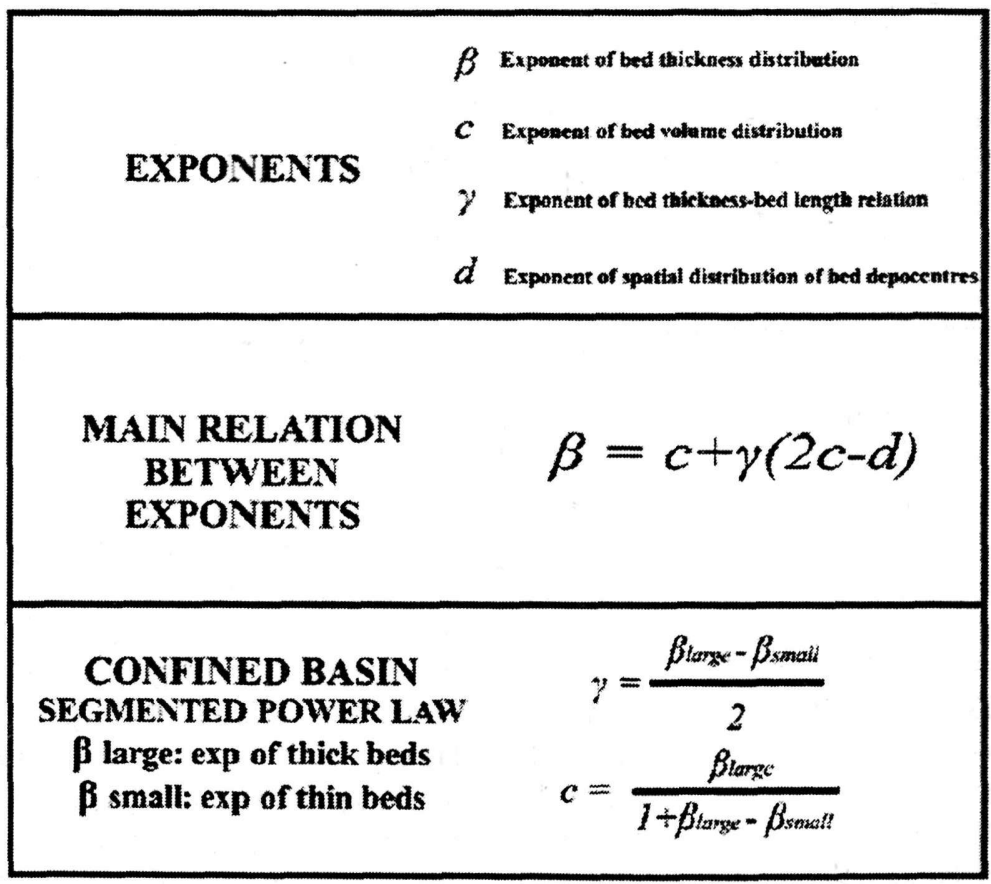

Table 2. Equations and exponents of the Malinverno model (Malinverno 1997). 
arrangement of submarine fan deposits in a basin based on bed thickness distributions, which is an important component of hydrocarbon exploration in clastic sediments.

\section{Application to Karpathos subma- rine fan deposits}

\subsection{Field details}

A simple application of the cumulative bed thickness distribution in submarine fans was attempted. The distribution was applied in outcrops A and B (Fig. 2, 3). These two outcrops near Spoa settlement have been interpreted as outer fan deposits according to Mutti \& Ricci Lucchi (1972) model, based on outcrop observations of sedimentary structures. In these two outcrops, the thickness of sandstone beds was measured in centimeters. About two hundred and thirty seven (237) sandstone

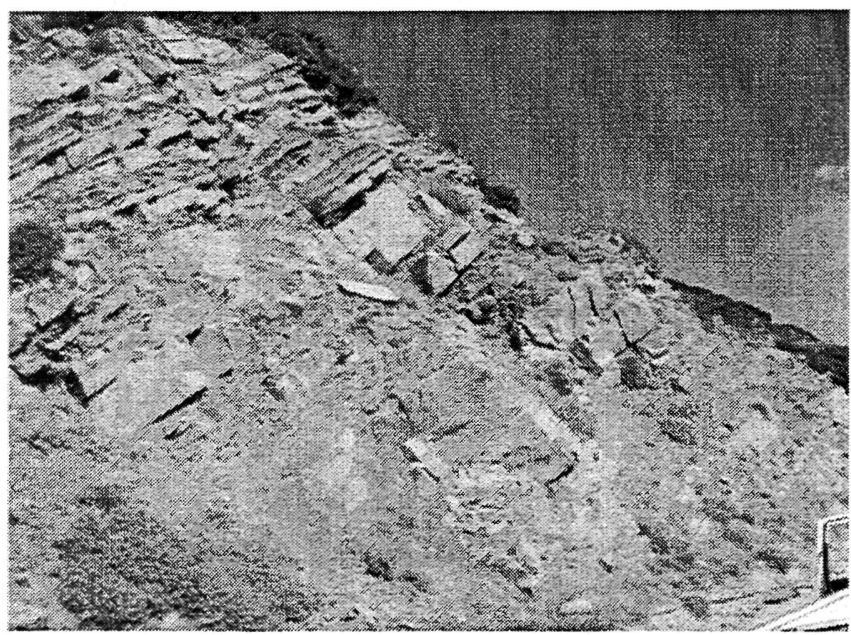

Fig. 2. Lower part of outcrop A. Alternations of fine grained sandstones (consisting mainly by very fine to medium sand) and mudstones can be observed.

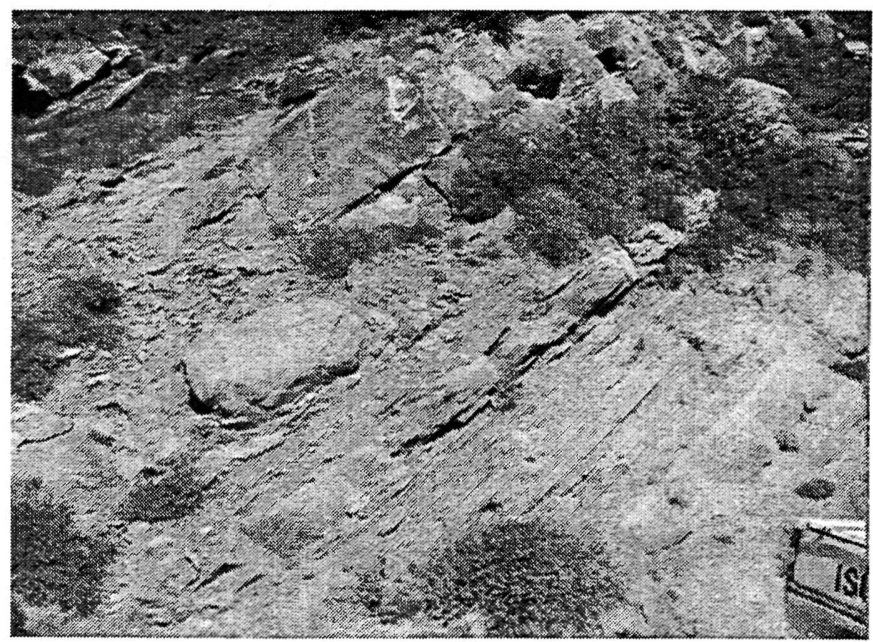

Fig. 3. Upper part of outcrop B. Fine grained thin bedded sandstones passing upwards into more coarse sandstones with characteristic Bouma Tabc divisions. 
beds were measured totally in the two outcrops. A minimal cut-off of one (1) cmwas established due to measuring difficulties below that thickness. Consequently the thickness of all sandstone beds from one (1) $\mathrm{cm}$ and above was measured in outcrops A and B.

\subsection{Outcrop A}

Outcrop $A$ has an exposed thickness of about thirty (30) meters. The thickness of one hundred and thirty six (136) sandstone beds above one (1) $\mathrm{cm}$ was recorded. About nine (9) amalgamated sandstone beds $(6.6 \%$ of the total) were observed in the outcrop. These beds are the product of more than one turbidity flows which were amalgamated into one bed and can be used as an indicator of erosion and amalgamation.

Bed thickness data of outcrop A show a rather good fit to the power law $\left(R^{2}=0.96\right)$ with an exponent (line gradient) of 0.82 in the cumulative log-log plot (Fig. 4).

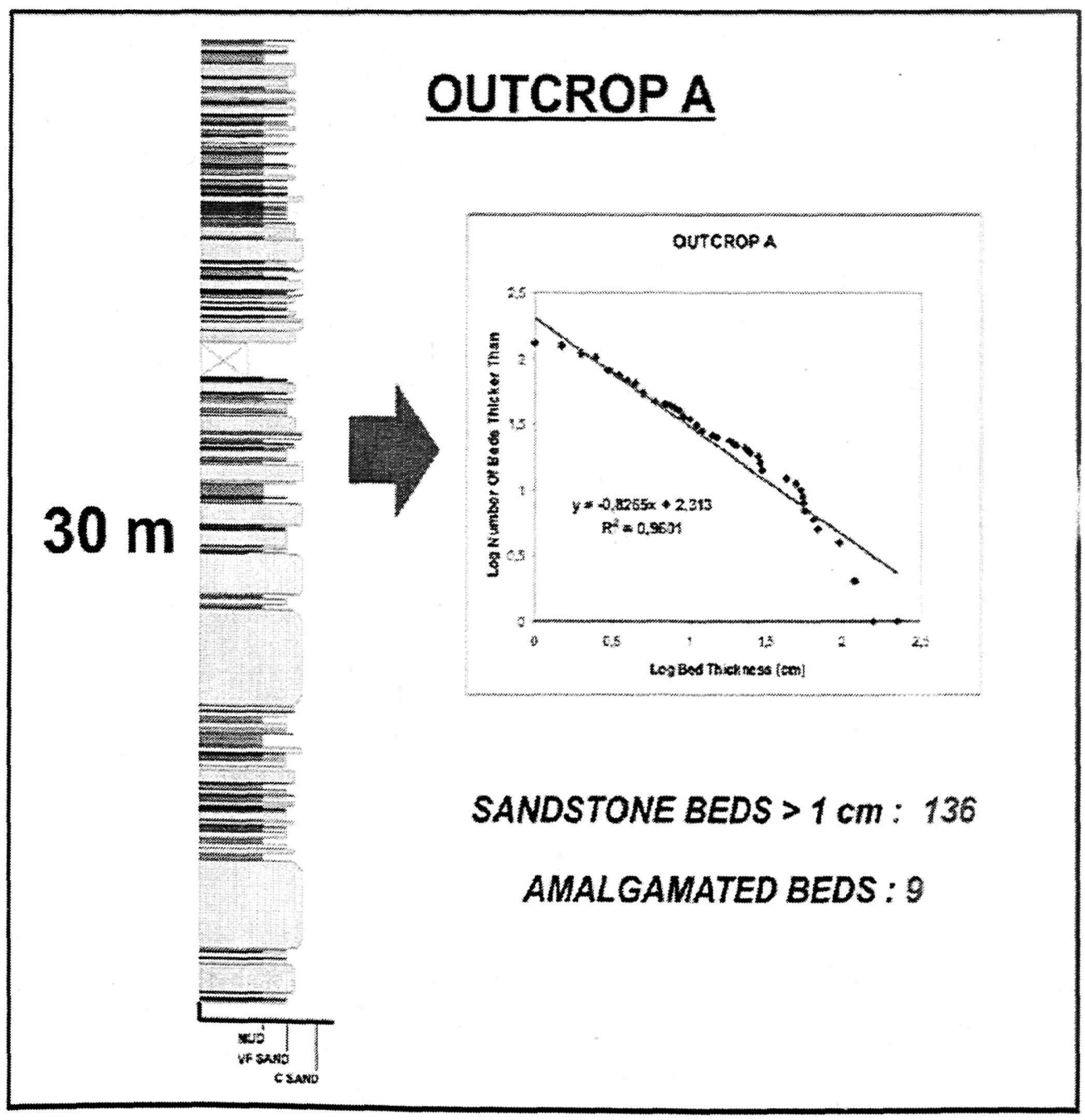

Fig. 4. Stratigraphic $\log$ and cumulative bed thickness distribution of outcrop A. 


\subsection{Outcrop B}

Outcrop B has an exposed thickness of about twenty (20) meters. The thickness of one hundred and one (101) sandstone beds above one (1) $\mathrm{cm}$ was recorded. About twenty eight (28) amalgamated sandstone beds $(27.7 \%$ of the total) were observed in the outcrop. Note the higher percentage of amalgamated beds than in outcrop A which indicates that erosion and amalgamation procedures were more frequent in outcrop $B$. Bed thickness data of outcrop $B$ show a good fit to the power law $\left(R^{2}=0.94\right)$ with an exponent (line gradient) of 0.91 in the cumulative log-log plot (Fig. 5).

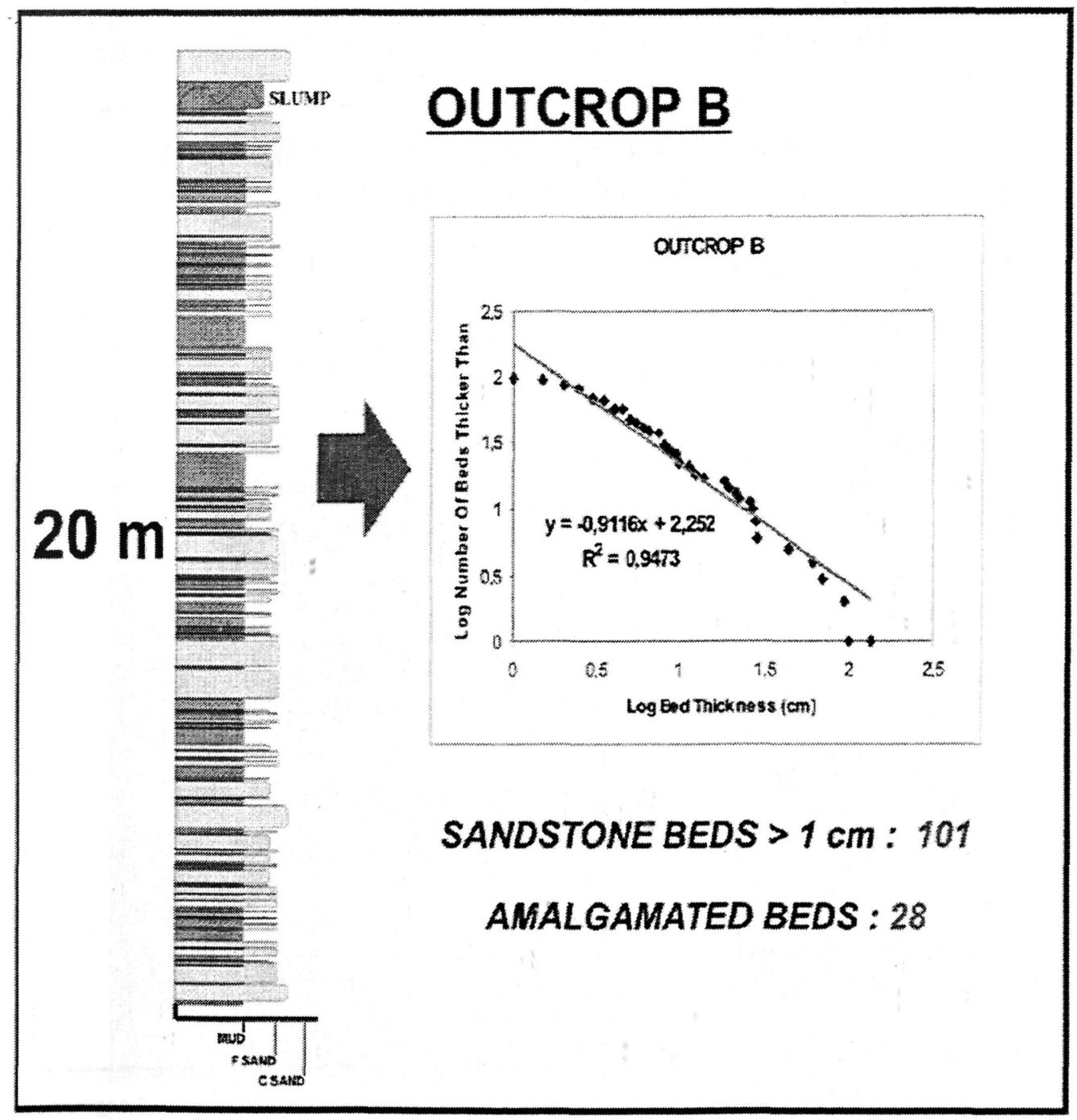

Fig. 5. Stratigraphic log and cumulative bed thickness distribution of outcrop $B$ 


\section{Discussion -}

\section{Basin Morphology}

The small thickness of External Hellenides submarine fan units in Karpathos compared to that in Western Greece indicates that sedimentation of these units in SE Greece took place in a minor extent compared to that in the West and probably in smaller, more confined sedimentary basins. The existence of geological evidence for a confined sedimentary basin led to the use of Malinverno's simplified equations to calculate the exponent of turbidite bed volumes, which gives very important information about the magnitude of turbidite events and the distribution of sand volume in the basin.

A segmented power law distribution was created from the bed thickness data of the two studied outcrops. The distribution is very well characterized $\left(R^{2}=0.97\right)$ by two linear trends (Fig. 6), one for the thin beds with exponent of $\beta$ small $=0.61$ and one for the thicker beds with an exponent of $\beta$ large $=1.63$. The exponent $c$ of the distribution of bed volumes was calculated by the Malinverno

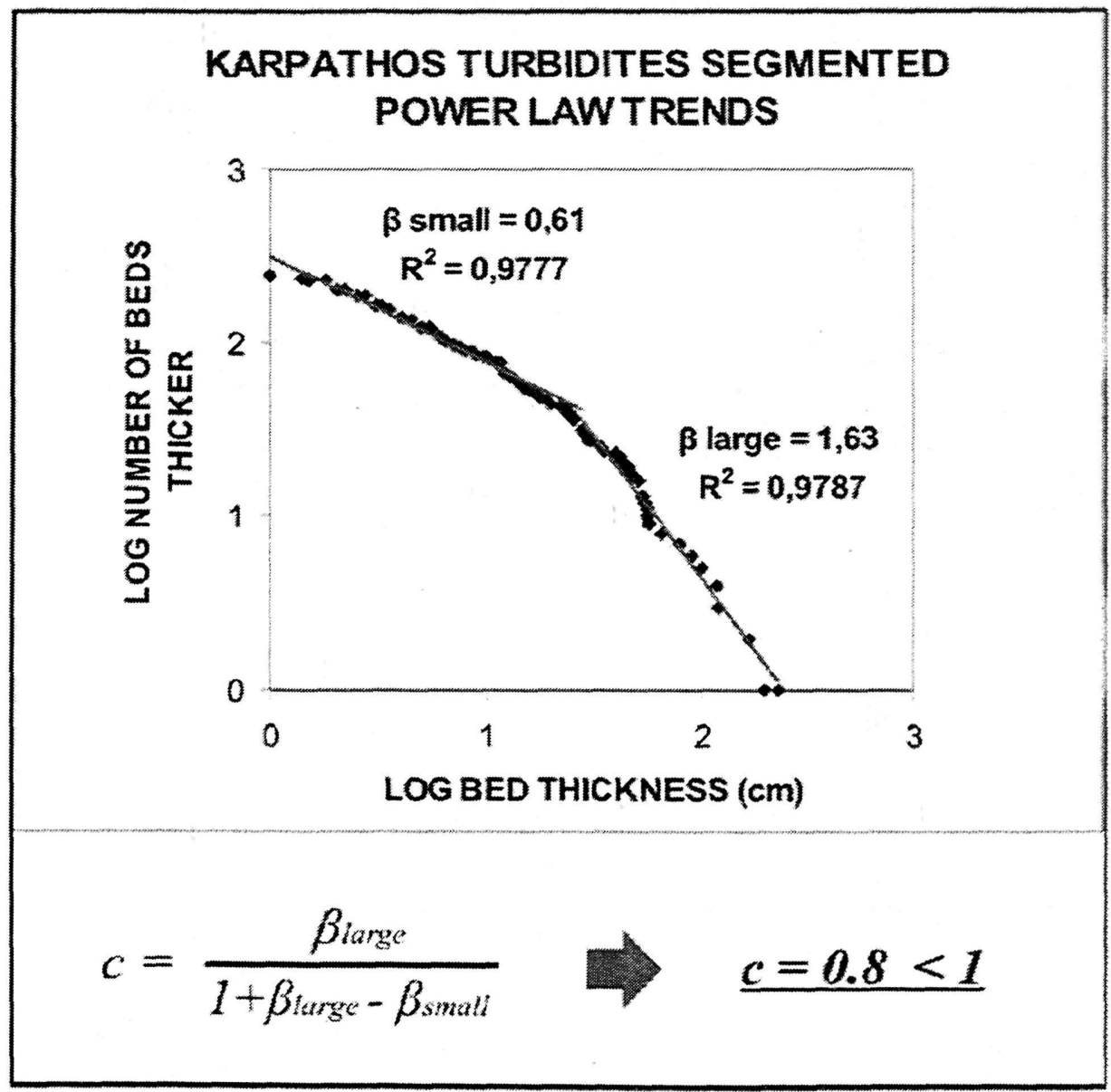

Fig. 6. Application of the Malinverno equation for confined basins in Karpathos turbidites. A segmented power law distribution was created and the resulting c exponent indicates "punctuated" turbidite sedimentation. 
equation and is equal to $c=0.8$.

The observation that $c<1$ according to Malinverno (1997) indicates that sand volume in the confined sedimentary basin is expressed by few thick beds and not by many thin beds thus turbidite sedimentation was dominated by few uncommon but large events (punctuated). The later is justified by the geological observations in Karpathos submarine fan deposits, where we can see very thick massive sandstone units (photo of Fig. 7) indicative of large scale submarine gravity flows.

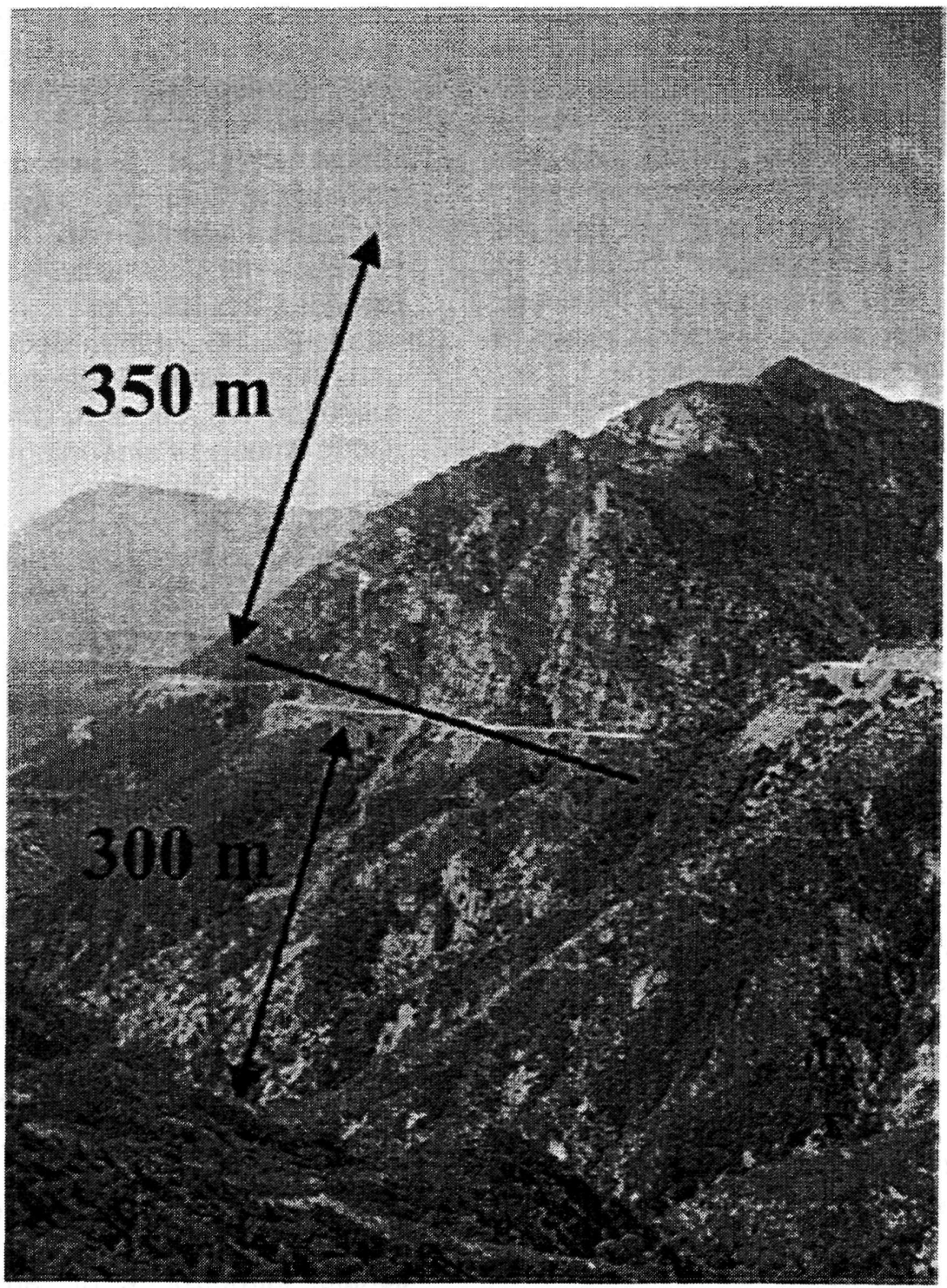

Fig. 7. Thick massive sandstone-conglomerate units $(350 \mathrm{~m})$, over a fine grained mudstone dominated unit $(300 \mathrm{~m})$, indicative of large scale submarine gravity flows (Spoa-Olympos road). 


\section{Conclusions}

Statistical analysis of sandstone bed thickness data from Karpathos submarine fan deposits in two outcrops gave important information about Tertiary turbidite sedimentation in SE Greece.

Bed thickness data in both outcrops is very well expressed by power law (fractal) distributions which justifies their classification into a distal to the sediment source depositional environment (Carlson \& Grotzinger 2001) and indicates a self-similarity of the turbidite system. Log-normal distributions were not observed in the studied outcrops.

A deviation from the power law was observed in the studied outcrops as erosion and amalgamation increases. This observation supports Carlson \& Grotzinger (2001) propositions.

Power law bed thickness distributions of Karpathos turbidites possibly indicate a single sediment source of the turbidite system (Chakraborty et al. 2002) which probably was the ophiolite-carbonate nappe system of the island. A petrographic study of the submarine fan deposits will be helpful in the confirmation of this indication. Independent geological evidence for a confined basin and the use of the equivalent Malinverno equation for the calculation of the sand bed volume exponent $c$ showed that the area was characterized by "punctuated" turbidite sedimentation (Malinverno 1997). This means that sand volume in the basin is distributed mainly in few thick beds. The later is justified by the geological observations in the field and has immediate applicability in hydrocarbon exploration because these thick sandstone beds constitute ideal hydrocarbon reservoirs.

\section{Acknowledgments}

This study is confounded by E.C.,
European Social fund and GSRT Greece. EPAN, PENED '03ED497.

\section{References}

Bouma, A.H., 1962. Sedimentology of Some Flysch Deposits: A Graphic Approach to Facies Interpretation. Amsterdam, Elsevier, p 168.

Carlson, J., \& Grotzinger, J.P., 2001. Submarine fan enviroment inferred from turbidite thickness distributions. Sedimentology, 48, 1331-1351.

Chakraborty, P.P., et al., 2002. Statistical appraisal of bed thickness patterns in turbidite successions, Andaman Flysch Group, Andaman Islands, India. Journal of Asian Earth Sciences, 21, 189-196.

Christodoulou, G., 1960. Geologische und mikropalaontologische untersuchugen auf der insel Karpathos (Dodekanes). Palaeontographica, A115, s. 143, Munchen.

Christodoulou, G., 1967. Late Eocene foraminifera from the Karpathos flysch. University of Thessaloniki Physics- Mathematics Department Review, 10, 163-167, Thessaloniki (in Greek with English abstract).

Davidson, J., 1974. Contribution a l'etude geologique de l'arc egeen: l'ile de Karpathos (Dodecanese meridional, Grece). These 3e cycle. Trav. Dept. Geol. Paris.

Fitrolakis, N., 1989. Contribution to the knowledge of the pre-Neogene of Karpathos. Bull. Geol. Soc. Greece, 23/1, 119-130 (in Greek with English abstract).

Malinverno, A., 1997. On the power law distribution of turbidite beds. Basin Research, 9, 263-274.

Mutti, E. and Ricci Lucchi, F., (1972), Le torbiditi dell' Appennine settentionale: introduzione al l'analisi di facies. Memone Societa Geologica 
Italiana, 11, 161-199. (Translated in English by T.H. Nilsen, (1978) International Geology Review, 20, no. 2, 125-166).

Mutti, E., 1985. Turbidite systems and their relations to depositional sequences, In: Provenance of aren- ites. Dordrecht, D. Reidel, 65-93.

Sadler, P.M., 1982. Bed thickness and grainsize ofturbidites. Sedimentology, 29, 37-51.

Talling, P.J., 2001. On the frequency distribution of turbidite thickness. Sedimentology, 48, 1297-1329. 